\title{
(+)-4-Carboxymethyl-2,4-dimethylbut-2-en-4-olide as dead-end metabolite of 2,4-dimethylphenoxyacetic acid or 2,4-dimethylphenol by Alcaligenes eutrophus JMP 134
}

\author{
D. H. Pieper*, K. H. Engesser, and H.-J. Knackmuss \\ Institut für Mikrobiologie der Universität Stuttgart, W-7000 Stuttgart, Federal Republic of Germany
}

Received April 21, 1990/Accepted August 10, 1990

\begin{abstract}
Dimethylphenoxyacetic acid and 2,4-dimethylphenol are not growth substrates for Alcaligenes eutrophus JMP 134 although being cooxidized by 2,4dichlorophenoxyacetate grown cells. None of the relevant catabolic pathways were induced by the dimethylphenoxyacetate. 3,5-Dimethylcatechol is not subject to metacleavage. The alternative ortho-cleavage is also unproductive and gives rise to (+)-4-carboxymethyl-2,4-dimethylbut-2-en-4-olide as a dead-end metabolite. High yields of this metabolite were obtained with the mutant Alcaligenes eutrophus JMP 134-1 which constitutively expresses the genes of 2,4-dichlorophenoxyacetic acid metabolism.
\end{abstract}

Key words: 2,4-Dimethylphenoxyacetic acid - 2,4-Dimethylphenol - 4-Carboxymethyl-2,4-dimethylbut-2en-4-olide - Alcaligenes eutrophus JMP 134 - Orthocleavage

Observations accumulated which indicate that chloroand methylsubstituted aromatic compounds are incompatible growth substrates when present at certain relative concentrations (Reineke et al. 1982; Schmidt et al. 1985; Taeger et al. 1988). In order to accomplish simultaneous utilization of both methyl- and chloroaromatics the construction of a bifunctional ortho-cleavage pathway was suggested (Knackmuss 1984) and finally realized by patchwork assembly of pathway segments in a single organism (Rojo et al. 1987).

Chloroaromatics can be degraded without difficulties via modified ortho-cleavage pathways (Reineke 1984; Reineke and Knackmuss 1988). Catabolism of analogous methylaromatics via ortho-cleavage pathways, however,

Present address: Institut für Biochemische Pflanzenpathologie, Gesellschaft für Strahlen- und Umweltforschung mbH, W-8042 Neuherberg, Federal Republic of Germany

Offprint requests to: $\mathrm{K}$. H. Engesser was shown to generate methylsubstituted 4-carboxymethylbut-2-en-4-olides as dead-end metabolites (Catelani et al. 1971; Knackmuss et al. 1976). The existence in nature of a catabolic sequence for the productive degradation of 4-methylcatechol via an ortho-cleavage route has recently been described in Alcaligenes eutrophus JMP 134 (Pieper et al. 1985) and Rhodococcus ruber N 75 (Bruce and Cain 1988). An isomerase catalyzing the transformation of 4-carboxymethyl-4-methylbut-2-en-4olide into the 3-methyl-isomer was identified as the key enzyme of this novel methyloxoadipate-pathway.

To find out whether dimethylsubstituted aromatic compounds can also be assimilated via this pathway, catabolism of 2,4-dimethylphenoxyacetic acid (2,4-MPA) by Alcaligenes eutrophus JMP 134 was investigated as a model system. Strain JMP 134 was found to be a versatile organism because it assimilates various substituted phenoxyacetic acids. Besides 2,4-dichlorophenoxyacetic acid (2,4-D) the analogous substrates 4-chloro-2-methyland 2-methylphenoxyacetic acid are readily utilized. 2,4Dimethylphenoxyacetic acid, however, is only cooxidized and is not a growth substrate (Pieper et al. 1988). In the present paper the catabolic steps which prevent total breakdown and assimilation of this compound are investigated in greater detail.

\section{Materials and methods}

\section{Organisms}

Alcaligenes eutrophus JMP 134 was isolated with 2,4-dichlorophenoxyacetic acid $(2,4-\mathrm{D})$ as sole source of carbon and energy (Pemberton et al. 1979). Alcaligenes eutrophus JMP 134-1 is a spontaneous mutant of this strain (Pieper et al. 1989).

\section{Culture conditions}

For growth in liquid culture mineral medium as described by Dorn et al. (1974) was used. It contained $5 \mathrm{mM}$ of the organic substrate with the exception of 2-methylphenol which was added at a concen- 
tration of $2 \mathrm{mM}$. Cells were grown in 100 or $1000 \mathrm{ml}$ fluted Erlenmeyer flasks containing 10 or $100 \mathrm{ml}$ of medium, respectıvely. The flasks were incubated at $30^{\circ} \mathrm{C}$ on a rotary shaker at $150 \mathrm{rpm}$.

For accumulation of metabolites, if not otherwise stated, resting cells of Alcaligenes eutrophus JMP 134 pregrown on 2.4-D. 2-MPA or 2-methylphenol and of A. eutrophus 134-1 pregrown on fructose were used. Harvested cells were resuspended in phosphate buffer $(\mathrm{pH} 7.4,50 \mathrm{mM})$ and incubated at $30^{\circ} \mathrm{C}$ with the respective substrate.

\section{Induction experiments}

Cells were grown in $500 \mathrm{ml}$ fluted Erlenmeyer flasks contaning $50 \mathrm{ml}$ medium and fructose as carbon source. During late exponential growth phase, this culture was transferred into a $3000 \mathrm{ml}$ flask, containing $500 \mathrm{ml}$ of medium, supplemented with fructose $(5 \mathrm{mM})$ and the inducer $(2 \mathrm{mM})$. Cells were harvested after $15 \mathrm{~h}$ of incubation at $30^{\circ} \mathrm{C}$ on a rotary shaker at $150 \mathrm{rpm}$.

\section{Preparation of cell extracts}

Cell extracts were prepared as previously described (Pieper et al. 1988).

\section{Enzyme assays}

Activities of catechol 2,3-dioxygenase, catechol 1,2-dioxygenase, 2-hydroxymuconic semialdehyde hydrolase, cis, cis-muconate cycloisomerase, chloromuconate cycloisomerase, 4-carboxymethylenebut-2-en-4-olide hydrolase, 4-carboxymethylbut-3-en-4-olide hydrolase and maleylacetate reductase were determined as described by Pieper et al. (1988).

Isomerisation of 4-carboxymethyl-4-methylbut-2-ene-4-olide (4-methyl-2-enclactone) was measured by HPLC analysis using the solvent system described by Pieper et al. (1985). Disappearance of 4-methyl-2-enelactone as well as formation of 4-carboxymethyl-3methyl-but-2-ene-4-olide (3-methyl-2-enelactone) was determined. Protein was assayed by the Bradford procedure (Bradford 1976).

\section{Activities with whole cells}

Activities of 2,4-D monooxygenase and phenol hydroxylases were determined by measuring the uptake of substrates by high pressure liquid chromatography. In addition consumption of oxygen at the expence of phenoxyacetates was assayed polarographically by use of a Clark type electrode (Pieper et al. 1988). 4-Methyl-2-enelactone isomerase was measured by HPLC as described above. Protein was determined accordıng to Schmidt et al. (1963).

\section{Analytical methods}

The concentration of substrates and metabolites was determined by the HPLC system described by Pieper et al. (1985). Fructose was determined by Fehlings reagent. UV-spectra were determined with a Shimadzu UV 240 spectrophotometer. Mass spectra were recorded on a mass spectrometer MAT 711 from Varian. NMR spectra were recorded on a Bruker CXP 300 NMR spectrometer with Aspect 2000 software using tetramethylsilane as internal standard and $\mathrm{D}_{6}$-acetone as solvent. Optical activity was measured in aqueous solution with a Perkin-Elmer 241 polarimeter

\section{Chemicals}

Chemicals were those reported by Pieper et al. (1988). 2,4-Dimethylphenol was purchased from Aldrich Chemie, Steinheim, FRG. 4-Carboxymethyl-4-methylbut-2-en-4-olide was prepared as described by Knackmuss et al. (1976). The preparation of 4-carboxymethyl-2,4-dimethylbut-2-en-4-olide has been described by Hartmann et al. (1979)

\section{Results}

Despite long term exposure to 2,4-dimethylphenoxyacetic acid (2,4-MPA) as sole source of carbon and energy no growth of Alcaligenes eutrophus JMP 134 at the expense of this compound was observed. Neither 2,4-D monooxygenase nor any of the three phenol hydroxylating activities present in this strain (Pieper et al. 1988) were induced by incubation with 2,4-MPA. Ringcleavage activities of catechol 1,2-dioxygenase type I and type II (C120 I, C120 II, Pieper et al. 1988) and catechol 2,3-dioxygenase were essentially the same as in noninduced cells (Table 1). The same was true for lower pathway enzymes such as hydroxymuconic semialdehyde hydrolase, cis,cis-muconate cycloisomerase, chloromuconate cycloisomerase, 4-carboxymethylbut-3-en-4olide hydrolase and 4-carboxymethylenebut-2-en-4-olide hydrolase. The same negative results were obtained using 2,4-dimethylphenol as an inducer.

Although Alcaligenes eutrophus JMP 134-1 expressed the genes of 2,4-D monooxygenase and chlorophenolhydroxylase semiconstitutively and those of C120 II, dichloromuconate cycloisomerase (Kuhm et al. 1990) and dienelactone hydrolase constitutively (Pieper et al. 1989), this strain also did not grow with 2.4-MPA or 2,4dimethylphenol as sole sources of carbon and energy. Fructose-grown cells of this organism, which contained no meta-cleavage activity, metabolized 2,4-MPA with transient accumulation of 2,4-dimethylphenol (Fig. 1). The excretion of a single dead-end-metabolite was observed. Measurement of enzyme activities showed, that the activity of 2,4-D monooxygenase towards 2,4-MPA $(30 \mathrm{U} / \mathrm{g}$ protein, i.e. $80 \%$ of the activity found towards 2,4-D as substrate) was considerably higher than the activity of chlorophenol hydroxylase towards 2,4-dimethylphenol $(15 \mathrm{U} / \mathrm{g}$ protein, i.e. $25 \%$ of the activity found towards 2,4-dichlorophenol).

In JMP 134 or JMP 134-1 the possibility exists that 2,4-MPA and 2,4-dimethylphenol are funnelled into the meta-cleavage pathway. Therefore turnover of 2,4-dimethylphenol by 2-MPA- or 2-methylphenol-grown cells and 2,4-D-grown cells of JMP 134 was compared. Correspondingly fructose-grown cells of JMP 134-1 were exposed to 2,4-dimethylphenol. In 2,4-D-grown cells of JMP 134, beside two phenol hydroxylating activities only enzymes of the ortho-cleavage pathways were induced. 2-MPA-grown cells also exhibited some meta-cleavage activity (Pieper et al. 1988). In 2-methylphenol-grown cells high meta-cleavage activity and poor ortho-cleavage activities were observed (Pieper et al. 1988, 1989). Irrespective of the growth substrate comparable amounts of the same dead-end metabolite were accumulated during 
Table 1. Specific activities of catabolic enzymes from cells of Alcaligenes eutrophus JMP 134 induced with 2,4-dichlorophenoxyacetic acid (2,4-D), 2,4-dimethylphenoxyacetic acid (2,4-MPA) or 2,4-dimethylphenol

\begin{tabular}{|c|c|c|c|c|c|}
\hline \multirow[t]{2}{*}{ Enzym activity } & \multirow[t]{2}{*}{ Assay substrate } & \multirow{2}{*}{$\frac{\text { sp. act. }}{2.4-D}$} & \multirow{2}{*}{$\frac{[\mathrm{U} / \mathrm{g} \text { protein] }}{2.4 \mathrm{MPA}}$} & \multicolumn{2}{|c|}{ after induction with ${ }^{\mathrm{a}}$} \\
\hline & & & & $\begin{array}{l}\text { 2,4-Dimethyl- } \\
\text { phenol }\end{array}$ & Fructose \\
\hline 2,4-D monooxygenase & 2,4-D & 32 & $<1$ & $N^{b}$ & 6 \\
\hline Phenol hydroxylase & $\begin{array}{l}\text { 2.4-Dichlorophenol } \\
\text { Phenol } \\
\text { 2-Methylphenol }\end{array}$ & $\begin{array}{l}130 \\
<5 \\
<5\end{array}$ & $\begin{array}{l}13 \\
<5 \\
<5\end{array}$ & $\begin{array}{l}12 \\
<5 \\
<5\end{array}$ & $\begin{array}{l}12 \\
<5 \\
<5\end{array}$ \\
\hline Catechol 2,3-dioxygenase & Catechol & $<1$ & $<1$ & $<1$ & $<1$ \\
\hline $\begin{array}{l}\text { 2-Hydroxymuconic semialdehyde } \\
\text { hydrolase }\end{array}$ & $\begin{array}{l}\text { 2-Hydroxy-6-oxohepta- } \\
\text { 2,4-dienoate }\end{array}$ & $<10$ & $<10$ & $<10$ & $<10$ \\
\hline Catechol 1,2-dioxygenase & $\begin{array}{l}\text { Catechol } \\
\text { 3-Chlorocatechol }\end{array}$ & $\begin{array}{l}310 \\
190\end{array}$ & $\begin{array}{r}10 \\
8\end{array}$ & $\begin{array}{l}8 \\
8\end{array}$ & $\begin{array}{r}6 \\
10\end{array}$ \\
\hline Muconate cycloisomerase & $\begin{array}{l}\text { cis-cis-muconate } \\
\text { 2,4-dichloro-cis.cis-muconate }\end{array}$ & $\begin{array}{l}<5 \\
240\end{array}$ & $\begin{array}{l}<5 \\
<5\end{array}$ & $\begin{array}{l}<5 \\
<5\end{array}$ & $\begin{array}{l}<5 \\
<5\end{array}$ \\
\hline $\begin{array}{l}\text { 4-Carboxymethylbut-3-en-4-olid } \\
\text { hydrolase }\end{array}$ & $\begin{array}{l}\text { 4-Carboxymethylbut-3- } \\
\text { en-4-olide }\end{array}$ & 60 & 20 & 30 & 30 \\
\hline $\begin{array}{l}\text { 4-Carboxymethylenebut-2- } \\
\text { en-4-olide hydrolase }\end{array}$ & $\begin{array}{l}\text { trans-4-Carboxymethylenebut- } \\
\text { 2-en-4-olide }\end{array}$ & 760 & 70 & 65 & 55 \\
\hline
\end{tabular}

a Cells were harvested after $15 \mathrm{~h}$ of induction. Enzyme activities of 2,4-D monooxygenase and phenol hydroxylases were determined with whole cells. All other activities were determined in cell extracts

${ }^{b} N D=$ not determined

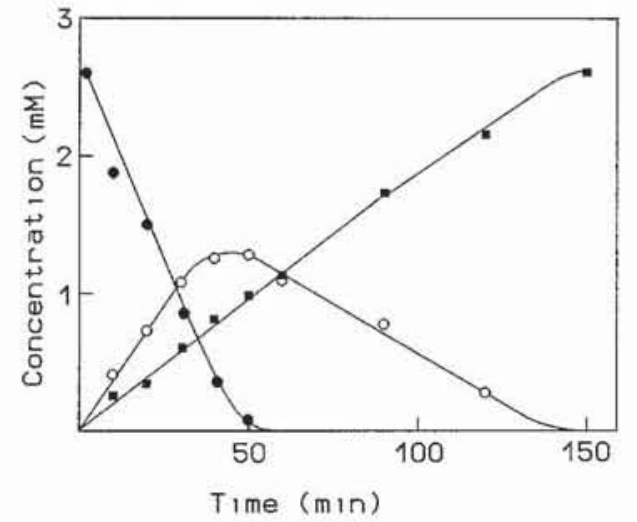

Fig. 1. Cooxıdatıon of 2.4-dimethylphenoxyacetic acid by fructosegrown cells of Alcaligenes eutrophus JMP 134-1. Fructose-grown cells of Alcaligenes eutrophus JMP 134-1 were suspended in phosphate buffer $\left(50 \mathrm{mM}, \mathrm{pH} 7.4, \mathrm{OD}_{546 \mathrm{~nm}} 15\right)$. Concentrations of 2,4-dimethylphenoxyacetic acid (-), 2.4-dimethylphenol (O) and 4-carboxymethyl-2,4-dimethylbut-2-en-4-olide (E) were determined by HPLC

cooxidation of 2,4-dimethylphenol. This indicated that meta-cleavage is not involved in formation of this metabolite.

To identify the structure of the dead-end metabolite JMP 134-1 was pregrown on fructose. After being harvested cells were suspended in phosphate buffer (11, $\mathrm{OD}_{546 \mathrm{~nm}}=12$ ). 2,4-Dimethylphenol was added in 5 portions of $0.5 \mathrm{mmol}$ each. After total conversion of the phenol, the metabolite was extracted from the acidified cell free supernatant with ethylacetate. After evaporation of ethylacetate, a brownish oil was obtained which was crystallized from diisopropylether. The UV-spectrum $\left(\lambda_{\max }=211 \mathrm{~nm}\right)$ was identical with that reported for 4-carboxymethyl-2,4-dimethylbut-2-en-4-olide (2,4-dimethyl-2-enelactone) by Hartmann et al. (1979). The mass spectrum also showed a fragmentation pattern which corresponds to that observed for 2,4-dimethyl-2enelactone $\left(\mathrm{M}^{+}\right.$at $\mathrm{m} / \mathrm{e}=170$ and prominent fragments due to loss of $\mathrm{CH}_{2} \mathrm{COOH}, \mathrm{HCOOH}$, and $\mathrm{CH}_{3}$ ). ${ }^{1} \mathrm{H}$ NMR data also coincidated with those given by Hartmann et al. (1979) for 2,4-dimethyl-2-enelactone. Two protons of a methylene-group resonate at 2.72 and $2.87 \mathrm{ppm}$, respectively. The signals were split into doublets due to a geminal coupling of $15.6 \mathrm{~Hz}$. A vinylic proton appears at $\delta=7.37 \mathrm{ppm}(\mathrm{q}, \mathrm{J}=1.6 \mathrm{~Hz})$. Two methylgroups resonate at $\delta=1.82 \mathrm{ppm}(\mathrm{d}, \mathrm{J}=1.6 \mathrm{~Hz})$ and $1.52 \mathrm{ppm}(\mathrm{s})$. The melting point of $72^{\circ} \mathrm{C}$ described by Hartmann et al. was also certified. Retention properties on reverse phase HPLC of the metabolite and of authentic 2,4-dimethyl-2-enelactone were identical. The isolated metabolite was optically active $[x]_{\mathrm{D} 25}=$ $+20.5^{\circ} \pm 0.1^{\circ}(\mathrm{c}=8.84 \mathrm{mg} / \mathrm{ml}$ water $)$.

The key enzyme of methylarene catabolism via ortho-cleavage which isomerizes 4-carboxymethyl-4methylbut-2-en-4-olide (4-methyl-2-enelactone) to 4-carboxymethyl-3-methylbut-2-en-4-olide (3-methyl-2-enelactone) was not induced in cells incubated with 2,4MPA. Activity with 4-methyl-2-enelactone measured in cell extracts was very low ( $20 \mathrm{U} / \mathrm{g}$ protein) compared with the activity measured in 4-methyl-2-enelactone-grown cells $(600 \mathrm{U} / \mathrm{g}$ protein). 4-Methyl-2-enelactone-grown cells did not convert 2,4-dimethyl-2-enelactone $(\leq 1 \mathrm{U} / \mathrm{g}$ protein), although 4-methyl-2-enelactone isomerase was 


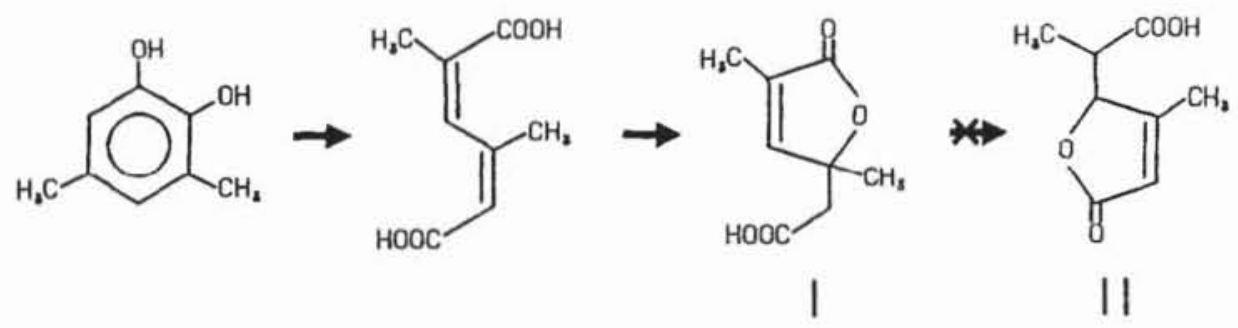

Fig. 2. Metabolism of 3.5-dımethylcatechol by Alcaligenes eutrophus JMP 134. I, 4-Carboxymethyl-2,4-dimethylbut-2-en-4-olide (2,4-dimethyl-2-enelactone), is formed as dead-end product. Its isomerization to II, 4-(1-carboxyethyl)-3-methylbut-2-ene-4-olide was not observed

present at a high level. To exclude restricted substrate uptake, crude extract of 4-methyl-2-enelactone-grown cells was incubated with 2,4-dimethyl-2-enelactone. Again, no turnover of 2,4-dimethyl-2-enelactone was observed. Isomerization of 4-methyl-2-enelactone by purified isomerase (Pieper et al. 1990) was inhibited at about $20 \%$ only if the substrate $(100 \mu \mathrm{M})$ was incubated with a 20 -fold excess of 2,4-dimethyl-2-enelactone. This corresponds to a rather high inhibition constant of approximately $5 \mathrm{mM}$.

In order to prepare larger amounts of 2,4-dimethyl2-enelactone for use as growth substrate JMP 134-1 was pregrown in 31 of fructose-containing medium $(10 \mathrm{mM})$. This culture was inoculated into a fermenter containing 51 of mineral medium supplemented with $16 \mathrm{mM}$ fructose (initial $\left.\mathrm{OD}_{546 \mathrm{~nm}} 1.5\right)$. A small amount of 2,4-dimethylphenol $(0.5 \mathrm{mM})$ was added. As determined by HPLC, this compound was taken up at a rate of $3.3 \mu \mathrm{M} / \mathrm{min}$. During cooxidation, 2,4-dimethylphenol (corresponding to $100 \mathrm{nM}$ ) was pumped into the fermenter at a flow rate of $25 \mathrm{ml} / \mathrm{h}$. After reaching an $\mathrm{OD}_{546 \mathrm{~nm}}$ of 3 , fructose $(30 \mathrm{mM})$ and $80 \mathrm{ml}$ of a 100 -fold concentrated mineral salts solution (Dorn et al. 1974) were added and cooxidation of methylphenol was continued for $16 \mathrm{~h} .6 .1 \mathrm{~g}$ (= $=50 \mathrm{mmol}$ ) of 2,4-dimethylphenol had been oxidized after that time. Accumulation of the dead-end metabolite 2,4-dimethyl-2-enelactone was nearly quantitative as calculated from HPLC data. At the end of the cooxidation experiment an $\mathrm{OD}_{546 \mathrm{~mm}}$ of 17 had been reached and fructose had been degraded completely. The cell free supernatant was concentrated by flush evaporation to a volume of $800 \mathrm{ml}$, acidified to $\mathrm{pH} 2.2$ with $\mathrm{H}_{3} \mathrm{PO}_{4}$ and extracted 6 times with $500 \mathrm{ml}$ of ethylacetate each. After evaporation of the solvent the brownish oil was dissolved in three volumes of diisopropylether. 2,4-Dimethylenelactone crystallized from cold diisopropylether. After washing with cold diisopropylether $5.3 \mathrm{~g}$ ( $62 \%$ yield) of pure 2,4-dimethyl-2-enelactone were obtained.

\section{Discussion}

Studies on the degradation of certain dimethylphenols have shown that 2,3- and 3,4-dimethylcatechol are key metabolites which can be utilized via meta-cleavage pathways (Ribbons 1970). An essential feature for utilization of 2,4- and 3,5-dimethylphenol (Chapman and Hopper 1968; Hopper and Chapman 1971), which could give rise to 3,5-dimethylcatechol, is the oxidation of a methyl group instead of ring hydroxylation. In contrast, 2,4dichlorophenoxyacetic acid or 2-methylphenoxyacetic acid grown cells of Alcaligenes eutrophus JMP 134 readily cooxidize 2,4-dimethylphenol and 2,4-dimethylphenoxyacetic acid (2,4-MPA) to 3,5-dimethylcatechol and further via an ortho ring-cleavage mechanism.

Although 2,4-dimethylphenol and 2,4-MPA were readily cometabolized by JMP 134 they did not serve as growth substrates. The inefficiency of these compounds to serve as inducers is not a sufficient explanation, because the mutant JMP 134-1, expressing 2,4-D monooxygenase and chlorophenol hydroxylase semiconstitutively (Pieper et al. 1989), also did not grow with these substrates.

Dimethylsubstituted aromatic compounds are cooxidized by the chloroaromatic degrading organism Pseudomonas sp. B 13. This organism, when grown with 3-chlorobenzoate, cometabolized 3,5-dimethylbenzoate via 3,5-dimethylcatechol (Hartmann et al. 1979). Alcaligenes eutrophus JMP 134 is a better candidate for 3,5dimethylcatechol assimilation because it differs from Pseudomonas sp. B 13 in at least two aspects. Firstly, strain JMP 134 can degrade and assimilate 4-methylcatechol via a modified ortho-cleavage pathway. Secondly it harbors a meta-cleavage enzyme which functions in the assimilation of certain methylsubstituted aromatics. This enzyme, however, exhibits no activity against 3,5-dimethylcatechol. Consequently in either JMP 134 or JMP 134-1 2,4-MPA and 2,4-dimethylphenol were exclusively converted to 4-carboxymethyl-2,4-dimethylbut-2-en-4-olide (2,4-dimethyl-2-enlactone).

Like 4-carboxymethyl-4-methylbut-2-en-4-olide (4methyl-2-enelactone) the dimethylsubstituted lactone lacks a proton at the chiral carbon atom to undergo a shift of the double bond yielding a but-3-en-4-olide in the sense of the classical muconolactone isomerase reaction (Stanier and Ornston 1973). Instead 4-methyl-2enelactone is isomerized in JMP 134 to the 3-methyl2-enelactone, which is subsequently metabolized via a reaction sequence corresponding to the classical 3-oxoadipate pathway (Pieper et al. 1985). The 2,4-dimethyl2-enelactone, however, is not bound and consequently not transformed by the 4-methyl-2-enelactone isomerising enzyme (Fig. 2).

The ease of production of large amounts of optically pure 2,4-dimethyl-2-enelactone from 2,4-dimethylphenol by fructose-grown cells of JMP 134-1 opens the possi- 
bility to use this dead end metabolite as an enrichment substrate. Microorganisms which utilize this compound may harbor a complementary catabolic sequence with a new kind of methyl-2-enelactone isomerase or a completely different mechanism involving direct hydrolysis of the lactone ring. This catabolic potential together with the pJP4 encoded pathway creates the biochemical basis for the construction of a bifunctional ortho-cleavage route for simultaneous degradation of dichloro- and dimethylaromatics.

Acknowledgements. We thank K. Stadler-Fritzsche for perfect technical assistance. We thank J. Rebell and Dr. P. Fischer for assisting in ${ }^{1}$ H-NMR spectral analysis. Dr. W. Rozdzinski for assisting in mass spectral analysis and B. Hörsch for assisting in analysis of optical activity.

\section{References}

Bradford MM (1976) A rapid and sensitive method for the quantitation of protein utilizing the principle of protein-dye binding. Anal Biochem 72:248-254

Bruce NC, Cain RB (1988) $\beta$-Methylmuconolactone, a key intermediate in the dissimilation of methylaromatic compounds by a modified 3-oxoadipate pathway evolved in nocardioform actinomycetes. FEMS Microbiol Lett 50:233-239

Catelani D, Fiecchi A, Galli E (1971) (+)- $\gamma$-Carboxy- $\gamma$-methyl $\Delta x-$ butenolide. A 1,2-ring-fission product of 4-methylcatechol by Pseudomonas desmolyticum. Biochem J 121:89-92

Chapman PJ, Hopper DJ (1968) The bacterial metabolism of 2,4xylenol. Biochem J 110:491-498

Dorn E, Hellwig M, Reineke W, Knackmuss HJ (1974) Isolation and characterization of a 3-chlorobenzoate degrading Pseudomonad Arch Microbiol 99.61-70

Hartmann J, Reineke W, Knackmuss HJ (1979) Metabolism of 3-chloro-, 4-chloro- and 3,5-dichlorobenzoate by a Pseudomonad. Appl Environ Microbiol 37:421 - 428

Hopper DJ, Chapman PJ (1971) Gentisic acid and 1ts 3- and 4-methyl-substituted homologues as intermediates in the bacterial degradation of m-cresol, 3,5-xylenol and 2,5-xylenol Biochem J 122:19-28

Knackmuss HJ (1984) Biochemistry and practical implications of organohalide degradation. In: Klug MJ, Reddy CA (eds) Current perspectives in microbial ecology. American Society for Microbiology. Washington, DC. pp 687-693

Knackmuss HJ, Hellwig M. Lackner H, Otting W (1976) Cometabolism of 3-methylbenzoate and methylcatechols by a chlorobenzoate utilizing Pseudomonas: Accumulation of $(+)$ 2,5-dihydro-4-methyl- and (+)-2,5-dihydro-2-methyl-5-oxofuran-2-acetic acid. Eur J Appl Microbiol 2:267-276

Kuhm AE, Schlömann M, Knackmuss HJ, Pieper D (1990) Purification and characterization of dichloromuconate cycloiso- merase from Alcaligenes eutrophus JMP 134. Biochem J $266: 877-883$

Pemberton JM, Corney B, Don RH (1979) Evolution and spread of pesticide degrading ability among soil micro-organisms. In: Timmis KN, Pühler A (eds) Plasmids of medical, environmental and commercial importance. Elsevier/North Holland Biomedical Press, Amsterdam, pp 287-299

Pieper DH, Engesser KH, Don RH. Timmis KN. Knackmuss HJ (1985) Modified ortho-cleavage pathway in Alcaligenes eutrophus JMP 134 for the degradation of 4-methylcatechol. FEMS Microbiol Lett 29:63-67

Pieper DH, Reineke W, Engesser KH, Knackmuss HJ (1988) Metabolism of 2,4-dichlorophenoxyacetic acid, 4-chloro-2methylphenoxyacetic acid and 2-methylphenoxyacetic acid by Alcaligenes eutrophus JMP 134. Arch Microbiol 150:95102

Pieper DH, Engesser KH, Knackmuss HJ (1989) Regulation of catabolıc pathways of phenoxyacetic acids and phenols in Alcaligenes eutrophus JMP 134. Arch Microbiol 151:365-371

Pieper DH, Stadler-Fritzsche K. Knackmuss HJ, Engesser KH (1990) Purification and characterization of 4-methylmuconolactone methylisomerase, a novel enzyme of the modified 3oxoadipate pathway in the Gram-negative bacterium Alcaligenes eutrophus JMP 134. Biochem J (in press)

Reineke W (1984) Microbial degradation of halogenated aromatic compounds. In: Gibson DT (ed) Microbial degradation of organic compounds. Marcel Dekker, New York, Basel, pp 319360

Reineke W. Knackmuss HJ (1988) Microbial degradation of haloaromatics. Annu Rev Microbiol 42:263-287

Reineke W, Jeenes DJ, Williams PJ, Knackmuss HJ (1982) TOL plasmid pWWO in constructed halobenzoate-degrading Pseudomonas strains: prevention of meta pathway. J Bacteriol 150: $195-201$

Ribbons DW (1970) Specificty of monohydric phenol oxidations by meta cleavage pathways in Pseudomonas aeruginosa T1. Arch Microbiol 74:103-115

Rojo F, Pieper DH. Engesser KH, Knackmuss HJ, Timm1s KN (1987) Assemblage of ortho cleavage route for simultaneous degradation of chloro- and methylaromatics. Science 238: $1395-1398$

Schmidt E. Bartels I, Knackmuss HJ (1985) Degradation of 3-chlorobenzoate by benzoate or 3-methylbenzoate-utilizing culturs. FEMS Microbiol Ecol 31:381-389

Schmidt K, Liaaen Jensen S, Schlegel HG (1963) Die Carotinoide der Thiorhodaceae. I. Okenon als Hauptcarotinoid von Chromatium okenii Perty. Arch Mikrobıol 46:117-126

Stanier RY, Ornston LN (1973) The $\beta$-ketoadipate pathway. Adv Microb Physiol 9:89-151

Taeger K, Knackmuss HJ, Schmidt E (1988) Biodegradability of mixtures of chloro- and methylsubstituted aromatics: simultaneous degradation of 3-chlorobenzoate and 3-methylbenzoate. Appl Microbiol Biotechnol 28:603-608 